\title{
Food Safety Knowledge, Attitudes and Practices of Food Handlers along the Rice Value Chain of Uganda
}

\author{
Leatitiah Namubiru (Corresponding author) \\ Legal Metrology Department \\ Uganda National Bureau of Standards (UNBS) \\ P.O. Box 7062 Kampala, Uganda \\ Tel: +256-75-719-7106 E-mail: leatitiah.namubiru@unbs.go.ug
}

\begin{abstract}
Denis Male
Center for Tobacco Control in Africa, School of Public Health

Makerere University, P.O Box 7062, Kampala, Uganda

School of Food Technology, Nutrition and Bioengineering

College of Agricultural and Environmental Sciences

Makerere University, P.O. Box 7062 Kampala, Uganda

Tel:+256-75-266-5028 E-mail: maledenis@gmail.com
\end{abstract}

\section{Ivan Muzira Mukisa}

School of Food Technology, Nutrition and Bioengineering

College of Agricultural and Environmental Sciences

Makerere University, P.O. Box 7062 Kampala, Uganda

Tel: +256-77-541-4537Ｅ-mail: ivanmukisa@gmail.com

\author{
Yusuf Byenkya Byaruhanga \\ School of Food Technology, Nutrition and Bioengineering \\ College of Agricultural and Environmental Sciences \\ Makerere University, P.O. Box 7062 Kampala, Uganda \\ Tel: +256-77-244-5113 E-mail: ybbyaru@gmail.com
}

Received: January 2, 2022 Accepted: February 15, 2022 Published: February 18, 2022

doi:10.5296/jfi.v6i1.19431 URL: http://dx.doi.org/10.5296/jfi.v6i1.19431 


\section{Abstract}

Food handlers play a critical role in controlling food contamination from "farm to fork". Therefore, inadequate knowledge, poor attitudes and improper practices by food handlers pose a serious challenge to food safety. The aim of this study was to assess the knowledge, attitudes, and practices (KAP) of food handlers along the rice value chain of Uganda with the view of understanding factors that influence contamination of rice with aflatoxins, heavy metals and pesticides. A cross-sectional study, using a structured questionnaire through face-to-face interviews with 252 respondents was conducted in Butaleja, Gulu, Hoima, Kampala, Mutukula, Mbale and Mbarara districts. Categorical data was expressed as frequencies and percentages. The unique predictors of the KAP of rice handlers were defined using multivariate linear regression analysis. About $221(87.7 \%)$ food handlers knew about the occurrence and causes of aflatoxins contamination in rice. Changes in colour $(81.7 \%)$ and a musty smell $(82.9 \%)$ were perceived to indicate the presence of aflatoxins. The main preand post-harvest aflatoxin preventative practices identified were growing resistant rice varieties $(82.9 \%)$ and proper drying $(79.8 \%)$. Food handlers were generally not knowledgeable (73.4\%) about heavy metal contamination in rice. All food handlers used pesticides; however, $68.3 \%$ had never received formal training in pesticide use. Majority $(86.1 \%)$ of food handlers were aware of the harmful effects of pesticides but on the contrary, this did not significantly change their practices towards safe pesticide use. At multivariate level, education was the unique predictor for aflatoxins and heavy metal contamination. Pesticide contamination was mainly influenced by district of residence. Therefore, appropriate educational programs organized to train food handlers can promote food safety in the rice value chain of Uganda. Interventions by regulatory agencies to strengthen enforcement of laws related to contaminants through regular surveillance at the farm and retail outlets are necessary to ensure compliance by food handlers.

\section{Keywords: Rice Value Chain, Knowledge, Attitudes, Practices, Food handlers, Uganda}

\section{Introduction}

Rice is a priority crop in Uganda's National Development Plan III of 2020/21-2024/25 which aims at enhancing food security, household income, and export promotion (NPA, 2019). However, in recent years, there have been public health and food safety concerns related to aflatoxins, heavy metals and pesticide residues in rice (Chaiyarat et al., 2015; Simon et al., 2016; Kong et al., 2018; Korley Kortei et al., 2019). The prevalence of contaminants in rice underscores the importance of intensive monitoring of rice throughout the entire value chain to prevent or/and reduce the risk of contamination.

Aflatoxin contamination is common in developing tropical countries such as Uganda, where temperature and relative humidity create an atmosphere favorable for the proliferation of aflatoxigenic fungi (Omara et al., 2020). Aflatoxin contamination can occur pre-harvest, at harvesting level and post-harvest (Korley Kortei et al., 2019). Pre-harvest contamination occurs when the fungus infects the kernels via airborne conidia or when the kernels are damaged from insect feeding (Kumar et al., 2017). Harvesting rice immediately after irrigation increases the initial pod moisture and stimulates aflatoxin build up in the rice grains (Hodges \& Stathers, 2012). At post-harvest, inefficient and slow drying processes, drying on 


\section{$\triangle$ Macrothink}

bare ground, mechanical damage to the grains at the time of threshing and storage of rice in warm and humid rooms enhance aflatoxin contamination (Ray Lantin, 2019). Socio-economic factors including low aflatoxin awareness, food insecurity, informal marketing systems without strong regulations, inadequate transportation modes, unavailability of harvesting tools and lack of knowledge on appropriate pre and postharvest practices are similarly significant contributors to aflatoxin contamination (Ali, 2019; FAO, 2019 ). When consumed, aflatoxin-contaminated food results in adverse nutrition and health consequences (Benkerroum, 2020). Chronic exposure to aflatoxin leads to liver cancer and has been linked to childhood stunting (Bbosa et al., 2013). Acute exposure leads to aflatoxicosis, haemorrhage, liver damage, oedema, impaired digestion and death (Sarma et al., 2017). Aflatoxin contaminated rice can also adversely affect trade and the export market share (Elzupir et al., 2015; Ali, 2019).

Rice grown in heavy metal polluted soil or irrigated with heavy metal contaminated water accumulates elevated levels of heavy metals (Zulkafflee et al., 2019). Heavy metal contamination in rice can occur at preharvest and post-harvest level (Simon et al., 2016). Heavy metal contamination at preharvest in rice is caused by activities such as mining and the use of metal-based fertilizers, pesticides and herbicides (Li et al., 2014). The variety of rice grown, the region where rice is grown and the irrigation method used similarly contribute to heavy metal contamination at preharvest level (Honma et al., 2016; Marquez et al., 2018; Mwale, 2018; Simon et al., 2016). Post-harvest contamination of rice is determined by the milling technique and cooking process (Mwale, 2018). Contaminated rice can contribute significantly to dietary intake and bio accessibility of heavy metals (Omar et al., 2015). The continuous use of heavy metal contaminated rice endangers human health due to the bioaccumulation of heavy metals in the body (Zulkafflee et al., 2019). Chronic exposure to heavy metals causes cancer, learning disabilities, skin lesions, abdominal pain, diarrhoea, diabetes, hypertension, respiratory disorders and cardiovascular diseases; hence making it a public health concern (Abtahi et al., 2017; Gomah et al., 2019).

In Uganda, rice cultivation remains traditionally based on subsistence production systems destined for mainly family consumption and marketing of the excess (Ntakyo \& van den Berg, 2019). However, with the reduction of the arable land, increasing demand of rice and rising pest attacks, the Ugandan rice value chain is increasingly using pesticides to enhance crop yield and shelf life (Barungi \& Odokonyero, 2016; Okello et al., 2019). The amount of pesticide residues found in food depends on the kind and dose of pesticide used during spraying, method of spraying employed, spraying period and integrated pest management both at preharvest and post-harvest level (Öztaş et al., 2018; European Parliament, 2021). Human exposure to pesticides occurs primarily through the oral, dermal and inhalation routes (Chen et al., 2020; Evangelou et al., 2016; Khammanee et al., 2020). Acute pesticide exposure results into excessive sweating, skin irritation, fatigue, dizziness, convulsion, coma and death (Chen et al., 2020; Khammanee et al., 2020; Swagata et al., 2021). Chronic exposure to pesticides may lead to cancer and gene mutation (Kim et al., 2016).

Food handlers knowledge of contaminants, attitudes towards, and the practices applied in relation to the knowledge are important determinants for the safety of food (Swagata et al., 


\section{MInstitute ${ }^{\text {Mink }}$}

2021). The level of knowledge, attitudes and practices (KAP) of food handlers in rice value chain of Uganda was previously unreported. The aim of this study was to assess the knowledge, attitudes and practices (KAP) of food handlers along the rice value chain of Uganda with the view of understanding factors that influence contamination of rice with aflatoxins, heavy metals and pesticides. This information is critical for guiding policy and intervention strategies to control contamination and promote food safety in the rice value chain of Uganda.

\section{Methodology}

\subsection{Study design and Sample size}

A cross-sectional study was conducted between February and May 2021. The study was conducted in Butaleja, Gulu and Hoima, Busia, Mbale, Mutukula and Kampala districts in Uganda. Purposive sampling was used to select the main districts that grow or /and trade in rice in Uganda. Multistage sampling was employed to identify the district, village, and finally a household or shop as the sampling frame. The population size in each selected district was identified from rice farmer groups and trader associations. The estimated sample size was obtained using an automated online calculator (Bukhari sample size calculator, 2020) at a predetermined 95\% confidence level and 5\% margin of error (Bukhari, 2020). A total sample size of 252 constituting of farmers and traders; Butaleja $(n=36)$, Gulu $(n=32)$, Hoima $(n=32)$, Busia $(n=36)$, Mbale $(n=36)$, Mutukula $(n=32)$ and Kampala $(n=48)$ were selected for this study.

\subsection{Data Collection}

The questionnaire was pretested using 30 rice handlers who were not included in the final survey. Necessary corrections were made to generate the final data collection tool. A total of 14 research assistants and 3 supervisors who had previous survey experience and could speak local languages were trained on the aim, the importance of confidentiality of information, respondent's right and procedures of interview prior to data collection. Data on food safety KAP of rice handlers was collected through face-to face interviews using the pretested structured questionnaire. The interviews were conducted in the local language for each region, English or both as deemed appropriate by the interviewer. Data collected entailed demographic characteristics of the respondents (district of residence, sex, age, marital status, family size, education and occupation) and knowledge, attitudes and practices of food handlers related to 3 common food hazards (aflatoxins, heavy metals and pesticide residues) along the rice value chain.

\subsection{Data Analysis}

The data were analysed using the SPSS statistical software, version 20 (SPSS Inc., Chicago, IL, USA). Descriptive statistics were used to summarize data on the demographics of food handlers (district of residence, gender, age, marital status, family size, education and occupation). Categorical data was expressed as frequencies and percentages. Knowledge was investigated through simple-dichotomy statements with one point awarded for each correct response while no point was given for a wrong response (True- $=1$, False $=0$ ). The attitudes of food handlers were measured using Likert's rating scale statements using the perception 


\section{1) Macrothink}

indices ( 1 = strongly disagree, $2=$ disagree, $3=$ indifferent, $4=$ agree and $5=$ strongly agree $)$. Practices were examined using frequency-determination statements (never $=0$ or ever $=1$ ). Bivariate regression analysis was used to test the existence of association between the KAP of food handlers and demographic characteristics. Selected independent variables with a significant Pearson correlation at 0.05 level (two tail) were further analysed using multivariable linear regression. The implicit model of the multiple regression was stated according to equation

$$
Y=f\left(X_{1}, X_{2}, X_{3}, X_{4}, X_{5}, X_{6}+e_{i}\right)
$$

Where:

$Y=$ Knowledge attitude and practices of rice handlers related to aflatoxin, heavy metal and pesticides contamination

$X_{1}=$ District of residence

$X_{2}=$ Gender

$X_{3}=$ Age

$X_{4}=$ Marital status

$X_{5}=$ Education

$X_{6}=$ Occupation

$e_{i} \quad=$ Error term

The relationship between the KAP of food handlers and demographic characteristics was explored. Statistical significance level was set at a $\mathrm{p}$-value $<0.05$. R square, unstandardized $\beta$ coefficient at $95 \%$ confidence interval were used to identify unique predictors of the KAP of food handlers.

\subsection{Ethical Statement}

Permission to conduct the study was obtained from the local leaders in each district and chairpersons of the farmer groups and trader organisations in a given area. Respondents were selected basing on their interest to participate. The respondents were adults ( $>18$ years of age) who were primary decision makers in the rice value chain. The study prepared an informed verbal consent that involved purpose of the research, expected duration of the interview, an explanation that the participants could withdraw from the interview at any time. This statement was read out to each participant before conducting the interview and his or her permission to be involved in the study requested. The study proposed a verbal consent overwritten one because the cross-sectional study was designed to collect descriptive data, responses obtained had no personal, social or political consequences and a significant number of respondents in the rice value chain had a low educational status.

\section{Results and Discussion}

\subsection{Socio-Demographic Characteristics of Food Handlers}

The socio-demographic characteristics of food handlers involved in this study are presented in Table 1. 


\section{Macrothink}

Journal of Food Industry

ISSN 1948-545X 2022, Vol. 6, No. 1

Table 1. Socio-demographic characteristics of the food handlers in the rice value chain of Uganda

\begin{tabular}{|c|c|c|}
\hline Variables & Frequency (n) & Proportion (\%) \\
\hline \multicolumn{3}{|l|}{ Gender } \\
\hline Male & 157 & 67.3 \\
\hline Female & 95 & 32.7 \\
\hline \multicolumn{3}{|l|}{ Age (years) } \\
\hline$<20$ & 26 & 10.3 \\
\hline $21-30$ & 46 & 18.2 \\
\hline $31-40$ & 101 & 40.0 \\
\hline $41-50$ & 51 & 20.2 \\
\hline $51-60$ & 15 & 5.9 \\
\hline$>60$ & 12 & 4.8 \\
\hline \multicolumn{3}{|l|}{ Marital status } \\
\hline Single & 27 & 10.7 \\
\hline Married & 225 & 89.3 \\
\hline \multicolumn{3}{|l|}{ Family size } \\
\hline$\leq 3$ & 40 & 15.8 \\
\hline $4-6$ & 103 & 40.8 \\
\hline $7-9$ & 88 & 34.9 \\
\hline$\geq 9$ & 21 & 8.3 \\
\hline \multicolumn{3}{|l|}{ Education } \\
\hline None & 28 & 11.1 \\
\hline Primary & 111 & 44.0 \\
\hline Secondary & 90 & 35.7 \\
\hline Tertiary & 23 & 9.1 \\
\hline \multicolumn{3}{|l|}{ Occupation } \\
\hline Full time farmer & 70 & 27.8 \\
\hline Permanent trader & 137 & 54.4 \\
\hline Temporary trader & 45 & 17.8 \\
\hline
\end{tabular}

$* \mathrm{~N}=252$ food handlers.

The study interviewed 252 respondents from 7 districts, with more male (67.3\%) than female $(32.7 \%)$ food handlers. Majority of the food handlers were of middle age with an average of 36.6 years and over $89 \%$ were married. The respondents' family sizes varied from 1 to 13 people, and the most represented class $(40.8 \%)$ had 4 to 6 members. About $88 \%$ attended school to acquire some education, indicating a measure of literacy. The majority $(82.2 \%)$ were engaged full time in the rice value chain as full-time farmers or permanent traders, the rest were temporary traders $(17.8 \%)$ who joined the rice business when rice was in season.

\subsection{Knowledge, Attitudes, and Practices of Food Handlers on Aflatoxin Contamination}

The knowledge of food handlers and the unique predictors of aflatoxin contamination are presented in Table 2 . 
Table 2. Knowledge of food handlers in the rice value chain of Uganda and the unique predictors of aflatoxin contamination

\begin{tabular}{|c|c|c|c|c|c|c|c|c|}
\hline \multirow{2}{*}{ Dependent variables } & \multirow{2}{*}{$\begin{array}{l}\text { Frequency } \\
\text { (percentage) } \\
\text { n }(\%)\end{array}$} & \multirow{2}{*}{$\begin{array}{l}\text { Significant } \\
\text { independent variables }\end{array}$} & \multirow{2}{*}{$\begin{array}{l}\text { Unique } \\
\text { predictor }\end{array}$} & \multirow{2}{*}{$\mathbf{R}^{2}$} & \multirow{2}{*}{$\beta$ coefficient } & \multirow{2}{*}{$\begin{array}{l}\text { Standard } \\
\text { error }\end{array}$} & \multicolumn{2}{|c|}{$\begin{array}{l}95 \% \quad \text { Confidence } \\
\text { interval for } \beta\end{array}$} \\
\hline & & & & & & & $\begin{array}{l}\text { Lower } \\
\text { bound }\end{array}$ & $\begin{array}{l}\text { Upper } \\
\text { bound }\end{array}$ \\
\hline \multicolumn{9}{|l|}{ Occurrence of aflatoxins } \\
\hline & & Education & & & & & & \\
\hline Aflatoxins can be present in rice & $221(87.7)$ & Age & Age & 0.38 & -0.90 & 0.21 & -0.132 & -0.048 \\
\hline & & Family size & & & & & & \\
\hline $\begin{array}{l}\text { Aflatoxin contamination occurs at } \\
\text { any time of rice growth }\end{array}$ & $208(82.5)$ & $\begin{array}{l}\text { Education } \\
\text { Age }\end{array}$ & Education & 0.58 & 0.24 & 0.26 & 0.187 & 0.288 \\
\hline $\begin{array}{l}\text { Aflatoxin contamination in rice can } \\
\text { occur in the field }\end{array}$ & $76(30.1)$ & $\begin{array}{l}\text { Education } \\
\text { Family size }\end{array}$ & Education & 0.42 & 0.32 & 0.30 & 0.272 & 0.391 \\
\hline $\begin{array}{l}\text { Aflatoxin contamination in rice can } \\
\text { occur during storage }\end{array}$ & $207(82.1)$ & $\begin{array}{l}\text { Education } \\
\text { Age }\end{array}$ & Education & 0.32 & 0.23 & 0.26 & 0.181 & 0.284 \\
\hline $\begin{array}{l}\text { Aflatoxins in rice can cross to the } \\
\text { table after harvest }\end{array}$ & $174(69.0)$ & Education & Education & 0.24 & 0.28 & 0.03 & 0.221 & 0.346 \\
\hline $\begin{array}{l}\text { Aflatoxins can be transferred into } \\
\text { breast milk }\end{array}$ & $77(30.5)$ & Education & Education & 0.34 & 0.38 & 0.03 & 0.279 & 0.395 \\
\hline $\begin{array}{l}\text { Aflatoxins can be transferred into } \\
\text { milk and dairy products }\end{array}$ & $79(31.3)$ & $\begin{array}{l}\text { Education } \\
\text { District }\end{array}$ & Education & 0.46 & 0.35 & 0.03 & 0.299 & 0.409 \\
\hline \multicolumn{9}{|l|}{ Cause of aflatoxin contamination } \\
\hline Aflatoxins are caused by fungi & $215(85.3)$ & $\begin{array}{l}\text { Education } \\
\text { Age }\end{array}$ & Education & 0.31 & 0.20 & 0.02 & 0.156 & 0.252 \\
\hline $\begin{array}{l}\text { High levels of rain during harvest } \\
\text { increase aflatoxin levels }\end{array}$ & $203(80.6)$ & $\begin{array}{l}\text { Education } \\
\text { Age }\end{array}$ & Education & 0.29 & 0.22 & 0.03 & 0.168 & 0.227 \\
\hline $\begin{array}{l}\text { Delayed harvesting promotes } \\
\text { aflatoxins contamination }\end{array}$ & $186(73.8)$ & $\begin{array}{l}\text { Education } \\
\text { District }\end{array}$ & District & 0.24 & 0.05 & 0.01 & 0.024 & 0.072 \\
\hline
\end{tabular}


Insect infestations promote aflatoxins contamination

Broken rice grains increase chances of contamination

204 (80.9) Education

Foreign materials promote aflatoxins contamination

$209(82.9) \quad$ Education

Poor storage conditions promote

aflatoxin contamination

Education

Age

Biotic factors that cause aflatoxin contamination*

$\begin{array}{lcl}\text { Microbial infection } & 189(75.0) & \begin{array}{l}\text { Education } \\ \text { District }\end{array} \\ \text { Insect infestation } & 199(78.9) & \begin{array}{l}\text { Education } \\ \text { District }\end{array} \\ & 195(77.4) & \begin{array}{l}\text { Education } \\ \text { District }\end{array}\end{array}$

Abiotic factors that cause aflatoxin contamination*

\begin{tabular}{|c|c|c|c|c|c|c|c|c|}
\hline High humidity & $191(75.7)$ & $\begin{array}{l}\text { Education } \\
\text { District }\end{array}$ & District & 0.26 & 0.05 & 0.01 & 0.021 & 0.068 \\
\hline High temperature & $83(32.9)$ & Education & Education & 0.43 & 0.38 & 0.03 & 0.326 & 0.436 \\
\hline Poor soils & $81(32.1)$ & Education & Education & 0.39 & 0.36 & 0.03 & 0.306 & 0.418 \\
\hline Drought stress & $83(32.9)$ & Education & Education & 0.43 & 0.38 & 0.03 & 0.326 & 0.436 \\
\hline
\end{tabular}

* Means more than one answer was reported (not mutually exclusive)

Values in parenthesis ( ) represent percentage. 


\section{Macrothink}

Of the 252 food handlers interviewed, $221(87.7 \%)$ knew about the possible existence of aflatoxins in rice. Among the 221 food handlers, $208(82.5 \%)$ knew that aflatoxins can be present in rice at any time of growth. Majority of the food handlers $(82.1 \%)$ stated that aflatoxin contamination occurs mainly at storage but not in the field $(30.1 \%)$. The respondents were generally knowledgeable about the fact that aflatoxins can be transferred to the table post-harvest $(68.7 \%)$. Fewer participants knew that aflatoxins could be present in breast milk (30.5\%) and dairy products (31.3\%). Biotic factors (mico organisms, insects and rodents) were perceived to potentially cause more aflatoxin contamination as compared to abiotic factors (humidity, temperature, drought and poor soils). Insect infestation (78.9\%), rodents in storage $(77.4 \%)$, and microbial infestation $(75 \%)$ were the commonest causes of aflatoxin contamination identified by the respondents.

In Uganda, aflatoxin contamination has been mainly studied in maize (Zea mays $L$ ), sorghum (Sorghum bicolor L), peanuts (Arachis hypogaea L), sunflower (Helianthus annus), sesame (Sesamum indicum L) and cassava (Manihot esculenta) (Echodu et al., 2019; Omara et al., 2020, Byakika et al., 2019, Angubua et al., 2017; Muzoora et al., 2017). However the possible existence of aflatoxin contamination in rice was reported in Saudi Arabia (Al-Zoreky $\&$ Saleh, 2019) and Colombia (Martinez-Miranda et al., 2019). Aflatoxin contamination has been similarly reported to occur at any time of rice growth (Elzupir et al., 2017). High relative humidity, water activity, temperature of rice and insect infestation were reported as critical factors that influence aflatoxin contamination at storage (Kumar et al., 2021). Similar studies reported breast milk and dairy products as major pathways for exposure to aflatoxins for young children (Magoha et al., 2016, Ali, 2019). Absence of stringent regulations and wide spread negligence of food handlers to control aflatoxin contamination in food and feed could possibly explain how aflatoxins find their way into breast milk and dairy products (Lukwago et al., 2019). The food handler's correlation between microorganisms and contamination could possibly explain why they felt that biotic factors are more likely to cause contamination as compared to abiotic factors (Negash, 2018).

The main demographic factors that significantly influenced knowledge of food handlers towards aflatoxin contamination were education, age and district where rice handlers lived (table 2). Multivariate linear regression showed that the level of education was the unique predictor that mainly influenced the knowledge of food handlers towards aflatoxin contamination. A similar study in Ethiopia reported the level of Education, formal training, and proper attitude towards food safety as the significant factors that reduce on food contamination (Alemayehu et al., 2021).

The attitude of food handlers and the unique predictors of aflatoxin contamination are presented in Table 3. 


\section{Macrothink}

Journal of Food Industry

ISSN 1948-545X

2022, Vol. 6, No. 1

Table 3. Attitude of food handlers in the rice value chain of Uganda and the unique predictors of aflatoxin contamination

\begin{tabular}{|c|c|c|c|c|c|c|c|c|}
\hline \multirow{2}{*}{$\begin{array}{l}\text { Dependent } \\
\text { variables }\end{array}$} & \multirow{2}{*}{$\begin{array}{l}\text { Frequency } \\
\text { (percentage) }\end{array}$} & \multirow{2}{*}{$\begin{array}{l}\text { Significant } \\
\text { independent } \\
\text { variables }\end{array}$} & \multirow{2}{*}{$\begin{array}{l}\text { Unique } \\
\text { predictor }\end{array}$} & \multirow[t]{2}{*}{$\mathbf{R}^{2}$} & \multirow{2}{*}{$\begin{array}{l}\beta \\
\text { coefficient }\end{array}$} & \multirow{2}{*}{$\begin{array}{l}\text { Standard } \\
\text { error }\end{array}$} & \multicolumn{2}{|c|}{$\begin{array}{l}95 \% \\
\text { Confidence } \\
\text { interval for } \beta\end{array}$} \\
\hline & & & & & & & $\begin{array}{l}\text { Lower } \\
\text { bound }\end{array}$ & $\begin{array}{l}\text { Upper } \\
\text { bound }\end{array}$ \\
\hline \multicolumn{9}{|c|}{ Rice that is discoloured may contain aflatoxins } \\
\hline Strongly agree & $158(62.7)$ & \multirow{5}{*}{$\begin{array}{l}\text { Education } \\
\text { Age }\end{array}$} & \multirow{5}{*}{ Education } & \multirow{5}{*}{0.406} & \multirow{5}{*}{0.610} & \multirow{5}{*}{0.054} & \multirow{5}{*}{0.504} & \multirow{5}{*}{0.716} \\
\hline Agree & $56(22.2)$ & & & & & & & \\
\hline No idea & $28(11.1)$ & & & & & & & \\
\hline Disagree & $10(3.97)$ & & & & & & & \\
\hline Strongly disagree & $0(0)$ & & & & & & & \\
\hline \multicolumn{9}{|c|}{ Rice that is differs in smell may contain aflatoxins } \\
\hline Strongly agree & $163(65.0)$ & & & & & & & \\
\hline Agree & $51(20.2)$ & \multirow{4}{*}{ Education } & \multirow{4}{*}{ Education } & \multirow{4}{*}{0.393} & \multirow{4}{*}{0.594} & \multirow{4}{*}{0.047} & \multirow{4}{*}{0.502} & \\
\hline No idea & $36(14.3)$ & & & & & & & 0.686 \\
\hline Disagree & $2(0.79)$ & & & & & & & \\
\hline Strongly disagree & $0(0)$ & & & & & & & \\
\hline Am aware of the harm & ul effects of af & toxins on hum & & & & & & \\
\hline Strongly agree & $164(65.1)$ & & & & & & & \\
\hline Agree & $54(21.4)$ & & & & & & & \\
\hline No idea & $61(24.2)$ & Fducation & Fducation & 0390 & 0572 & 0045 & 0.483 & 0661 \\
\hline Disagree & $0(0)$ & Lutuativin & Lutucativin & ט & 20.0 & נד & 0.70 & 0.001 \\
\hline Strongly disagree & $0(0)$ & & & & & & & \\
\hline Aflatoxins cause cance & in humans & & & & & & & \\
\hline Strongly agree & $194(76.9)$ & & & & & & & \\
\hline Agree & $24(9.52)$ & Fducation & & & & & & \\
\hline No idea & 34 (13.9) & $\begin{array}{l}\text { Age } \\
\text { Age }\end{array}$ & Education & 0.324 & 0.459 & 0.048 & 0.364 & 0.554 \\
\hline Disagree & $0(0)$ & & & & & & & \\
\hline Strongly disagree & $0(0)$ & & & & & & & \\
\hline Aflatoxins delay child & growth & & & & & & & \\
\hline Strongly agree & $23(9.1)$ & & & & & & & \\
\hline Agree & $25(9.92)$ & & & & & & & \\
\hline No idea & $171(67.9)$ & Education & Education & 0.256 & 0.475 & 0.51 & 0.374 & 0.576 \\
\hline Disagree & $33(13)$ & & & & & & & \\
\hline Strongly disagree & $0(0)$ & & & & & & & \\
\hline Aflatoxin contaminatic & $n$ can reduce th & price of rice & & & & & & \\
\hline Strongly agree & $197(78.2)$ & & & & & & & \\
\hline Agree & $16(6.34)$ & & & & & & & \\
\hline No idea & $37(14.7)$ & $\begin{array}{ll}\text { Age } \\
\text { Agucali }\end{array}$ & Education & 0.310 & 0.477 & 0.052 & 0.374 & 0.581 \\
\hline Disagree & $2(0.80)$ & & & & & & & \\
\hline Strongly disagree & $0(0)$ & & & & & & & \\
\hline Aflatoxin-contaminate & I rice cannot be & exported to son & e countries & & & & & \\
\hline Strongly agree & $194(76.9)$ & & & & & & & \\
\hline Agree & $21(8.33)$ & & & & & & & \\
\hline No idea & 35 (13.9) & Education & Education & 0.308 & 0.517 & 0.049 & 0.420 & 0.613 \\
\hline Disagree & $2(0.80)$ & & & & & & & \\
\hline Strongly disagree & $0(0)$ & & & & & & & \\
\hline
\end{tabular}

Values in parenthesis ( ) represent percentage. 


\section{Macrothink}

Food handlers perceived changes in colour $(81.7 \%)$ and a musty smell $(82.9 \%)$ to indicate the presence of aflatoxins. Interestingly, $86.5 \%$ had sufficient acuity on the harmful effects of aflatoxins in humans including cancer, but $80.9 \%$ were not aware of the fact that aflatoxins delay child growth. Among all the respondents, the proportion that thought that contamination could reduce the price of rice and exportation to some countries was $84.5 \%$ and $85.3 \%$, respectively

Comparable to this study, changes in colour and discoloration were reported as an indicator of aflatoxin contamination in cassava, maize and rice (Udomkun et al., 2018, Mahato et al., 2019). Dietary aflatoxin exposure has been reported to cause over $85 \%$ of the cases of hepatocellular carcinoma in low-income countries (Palliyaguru \& Wu, 2013). Aflatoxins cause stunting by inducing intestinal enteropathy, a subclinical condition of the small intestines, characterised by reduced absorptive capacity and increased intestinal permeability (Smith et al., 2012). Aflatoxin contamination was similarly reported to reduce the price of rice due to damage on the grains, rejection of aflatoxin contaminated produced and creation of a quality based non-tax barrier to trade (Kilimo Trust, 2018; Lukwago et al., 2019; Nkuba et al., 2016).

The main demographic factors that significantly influenced attitude of food handlers towards aflatoxin contamination in rice were education and age (Table 3). Multivariate linear regression showed that the level of education was the unique predictor that influenced the attitude of food handlers towards aflatoxin contamination.

The practices of food handlers and the unique predictors of aflatoxin contamination were presented in Table 4. 
Table 4. Practices of food handlers in the rice value chain of Uganda and the unique predictors of aflatoxin contamination

\begin{tabular}{|c|c|c|c|c|c|c|c|c|c|}
\hline \multirow{2}{*}{ Dependent variables } & \multirow{2}{*}{$\begin{array}{l}\text { Frequency } \\
\text { (percentage) }\end{array}$} & \multirow{2}{*}{$\begin{array}{l}\text { Significant } \\
\text { variables }\end{array}$} & \multirow[t]{2}{*}{ independent } & \multirow{2}{*}{$\begin{array}{l}\text { Unique } \\
\text { predictor }\end{array}$} & \multirow{2}{*}{$\mathbf{R}^{2}$} & \multirow{2}{*}{$\begin{array}{l}\beta \\
\text { coefficient }\end{array}$} & \multirow{2}{*}{$\begin{array}{l}\text { Standard } \\
\text { error }\end{array}$} & \multicolumn{2}{|c|}{$\begin{array}{l}95 \% \text { Confidence interval } \\
\text { for } \beta\end{array}$} \\
\hline & & & & & & & & $\begin{array}{l}\text { Lower } \\
\text { bound }\end{array}$ & $\begin{array}{l}\text { Upper } \\
\text { bound }\end{array}$ \\
\hline \multicolumn{10}{|c|}{ Preharvest control measures for aflatoxins* } \\
\hline Selection of healthy seeds & $45(17.9)$ & $\begin{array}{l}\text { Education } \\
\text { District }\end{array}$ & & Education & 0.28 & -0.06 & 0.01 & -0.077 & -0.036 \\
\hline $\begin{array}{l}\text { Seed treatments with } \\
\text { chemicals }\end{array}$ & $131(52.0)$ & $\begin{array}{l}\text { Education } \\
\text { Family size }\end{array}$ & & Education & 0.12 & 0.23 & 0.41 & 0.153 & 0.313 \\
\hline $\begin{array}{l}\text { Using resistant/specific } \\
\text { varieties }\end{array}$ & $209(82.9)$ & $\begin{array}{l}\text { Education } \\
\text { Age }\end{array}$ & & Education & 0.31 & 0.23 & 0.03 & 0.181 & 0.283 \\
\hline $\begin{array}{l}\text { Timely application of } \\
\text { fertilisers }\end{array}$ & $174(69.0)$ & Education & & Education & 0.16 & 0.23 & 0.03 & 0.163 & 0.294 \\
\hline Pesticide application & $179(71.0)$ & Education & & Education & 0.17 & 0.23 & 0.03 & 0.170 & 0.298 \\
\hline \multicolumn{10}{|c|}{ Postharvest control measures for aflatoxins* } \\
\hline Timely harvesting & $129(51.2)$ & $\begin{array}{l}\text { Education } \\
\text { Family size }\end{array}$ & & Education & 0.09 & 0.20 & 0.04 & 0.119 & 0.281 \\
\hline $\begin{array}{l}\text { Cleaning and sorting before } \\
\text { storage }\end{array}$ & $197(78.2)$ & Education & & Education & 0.21 & 0.24 & 0.03 & 0.179 & 0.292 \\
\hline Proper drying & $201(79.8)$ & $\begin{array}{l}\text { Education } \\
\text { Age }\end{array}$ & & Education & 0.24 & 0.22 & 0.03 & 0.160 & 0.274 \\
\hline Proper storage & $199(79.0)$ & Education & & Education & 0.22 & 0.24 & 0.03 & 0.181 & 0.292 \\
\hline Using pesticides & $141(56.0)$ & $\begin{array}{l}\text { Education } \\
\text { District }\end{array}$ & & District & 0.14 & 0.06 & 0.02 & 0.031 & 0.089 \\
\hline
\end{tabular}

* Means more than one answer was reported (not mutually exclusive).

Values in parenthesis ( ) represent percentage. 
More respondents believed that it was possible to manage aflatoxin contamination at post-harvest as compared to preharvest stage in rice (Table 4). Growing specific varieties of rice in a given region was identified as the main preharvest preventative strategy against aflatoxin contamination. Important post-harvest management practices cited were proper drying (82.9\%), cleaning crops before storage (78.2\%) and proper storage $(79 \%)$.

Similarly, aflatoxin management in rice was reported to be more effective at post-harvest than preharvest (Jeyaramraja et al., 2018; Mahuku et al., 2019). Using aflatoxin resistant varieties along with recommended farming practices was one of the preventative strategy recommended in a study in India (Kumar et al., 2021). Comparable to this study, rice farmers in Nigeria identified drying (74.44\%), cleaning (70.86\%), milling (70.00\%), packaging $(67.50 \%)$ and proper storage $(62.99 \%)$ as key post-harvest management practices that would control aflatoxin contamination (Adeola, 2020).

The main demographic factors that significantly influenced practices of food handlers with regards to aflatoxin contamination were education, age, family size and districts where rice handlers lived (table 4). Multivariate linear regression showed that the level of education was the unique predictor that mainly influenced the practices of food handlers towards aflatoxin contamination.

\subsection{Knowledge, attitude and practices of food handlers on heavy metal contamination}

Food handlers' knowledge of heavy metal contamination was presented in Table 5

The respondents were generally not conversant with heavy metal contamination in rice (Table 5 ). Of all respondents, only $26.6 \%$ were aware about the presence of heavy metals in rice. Only $8.7 \%$ of the food handlers thought that heavy metal contamination of rice could occur in the field. Among these respondents, $13.1 \%$ were aware of heavy metal contamination at the milling stage and felt that rice that is cooked and served could be contaminated by heavy metals (12.3\%). Several studies have reported the presence of $\mathrm{As}, \mathrm{Cd}$ and $\mathrm{Pb}$ in rice (Simon et al., 2016, Abtahi et al., 2017, Ndong et al., 2018).

According to a case study in the Jin-Qu Basin of China, heavy metal contamination in the field was attributed to rice's efficient assimilation of heavy metals from soils (Guo et al., 2020). Milling equipment and method of milling have been reported to determine the concentration of heavy metals introduced into food (Oniya et al., 2018, Adu et al., 2020). The level of education was the unique predictor that influenced the knowledge of food handlers towards heavy metal contamination. Similarly, the level of education was the unique predictor that influenced the attitudes of food handlers towards heavy metal contamination. 


\section{Macrothink}

Journal of Food Industry

ISSN 1948-545X

Table 5. Knowledge of food handlers in the rice value chain of Uganda and the unique predictors of heavy metal contamination

\begin{tabular}{|c|c|c|c|c|c|c|c|c|}
\hline Variables & $\begin{array}{l}\text { Frequency } \\
\text { (percentage) }\end{array}$ & $\begin{array}{l}\text { Significant independent } \\
\text { variables }\end{array}$ & $\begin{array}{l}\text { Unique } \\
\text { predictor }\end{array}$ & $\mathbf{R}^{2}$ & $\begin{array}{l}\beta \\
\text { coefficient }\end{array}$ & $\begin{array}{l}\text { Standard } \\
\text { error }\end{array}$ & $\begin{array}{l}95 \% \\
\text { interva } \\
\text { Lower } \\
\text { bound }\end{array}$ & $\begin{array}{l}\text { Confidence } \\
\beta \\
\text { Upper } \\
\text { bound }\end{array}$ \\
\hline \multicolumn{9}{|l|}{ Occurrence of heavy metals } \\
\hline Heavy metals can be present in rice & 67 (26.6) & $\begin{array}{l}\text { Education } \\
\text { District } \\
\text { Marital status }\end{array}$ & Education & 0.50 & 0.36 & 0.03 & 0.307 & 0.408 \\
\hline $\begin{array}{l}\text { I am aware of heavy metal } \\
\text { contamination of rice in the field }\end{array}$ & $22(8.7)$ & Education & Education & 0.20 & 0.16 & 0.02 & 0.117 & 0.195 \\
\hline $\begin{array}{l}\text { I am aware of heavy metal } \\
\text { contamination during milling }\end{array}$ & $33(13.1)$ & $\begin{array}{l}\text { Education } \\
\text { Marital status }\end{array}$ & Education & 0.32 & 0.24 & 0.02 & 0.192 & 0.278 \\
\hline $\begin{array}{l}\text { I am aware of heavy metals in rice } \\
\text { cooked and served }\end{array}$ & $31(12.3)$ & $\begin{array}{l}\text { Education } \\
\text { Marital status } \\
\text { District }\end{array}$ & Education & 0.32 & 0.21 & 0.02 & 0.163 & 0.251 \\
\hline
\end{tabular}

Values in parenthesis ( ) represent percentage. 
Table 6. Attitude of food handlers in the rice value chain of Uganda and the unique predictor of heavy metal contamination

\begin{tabular}{|c|c|c|c|c|c|c|c|c|}
\hline \multirow{2}{*}{ Variables } & \multirow{2}{*}{$\begin{array}{l}\text { Frequency } \\
\text { (percentage) }\end{array}$} & \multirow{2}{*}{$\begin{array}{l}\text { Significant independent } \\
\text { variables }\end{array}$} & \multirow{2}{*}{$\begin{array}{l}\text { Unique } \\
\text { predictor }\end{array}$} & \multirow{2}{*}{$\mathbf{R}^{2}$} & \multirow{2}{*}{$\beta$ coefficient } & \multirow{2}{*}{$\begin{array}{l}\text { Standard } \\
\text { error }\end{array}$} & \multicolumn{2}{|c|}{$95 \%$ Confidence interval for $\beta$} \\
\hline & & & & & & & Lower bound & Upper bound \\
\hline \multicolumn{9}{|c|}{ Heavy metals are harmful to human health } \\
\hline Strongly agree & 0 & & & & & & & \\
\hline Agree & $28(11.1)$ & & & & & & & \\
\hline No idea & $123(48.8)$ & Education & Education & 0.027 & 0.175 & 0.067 & 0.043 & 0.308 \\
\hline Disagree & $65(25.8)$ & & & & & & & \\
\hline Strongly disagree & $36(14.3)$ & & & & & & & \\
\hline \multicolumn{9}{|c|}{ Heavy metals cause liver damage in humans } \\
\hline Strongly agree & 0 & & & & & & & \\
\hline Agree & $17(6.8)$ & & & & & & & \\
\hline No idea & $134(53.2)$ & Education & Education & 0.069 & 0.287 & 0.067 & 0.156 & 0.418 \\
\hline Disagree & $52(20.6)$ & & & & & & & \\
\hline Strongly disagree & $49(19.4)$ & & & & & & & \\
\hline \multicolumn{9}{|c|}{ Heavy metals cause stunting in children } \\
\hline Strongly agree & 0 & & & & & & & \\
\hline Agree & $17(6.8)$ & & & & & & & \\
\hline No idea & $142(56.3)$ & Education & Education & 0.070 & 0.289 & 0.069 & 0.161 & 0.420 \\
\hline Disagree & $53(21.0)$ & & & & & & & \\
\hline Strongly disagree & $40(16.0)$ & & & & & & & \\
\hline \multicolumn{9}{|c|}{ Heavy metal-contaminated rice cannot be exported to some countries } \\
\hline Strongly agree & $9(3.6)$ & & & & & & & \\
\hline Agree & $16(6.4)$ & & & & & & & \\
\hline No idea & $138(54.8)$ & Education & Education & 0.084 & 0.313 & 0.065 & 0.185 & 0.442 \\
\hline Disagree & $64(25.4)$ & & & & & & & \\
\hline Strongly disagree & $20(7.9)$ & & & & & & & \\
\hline
\end{tabular}




\section{Macrothink $\Delta$ Institute ${ }^{\mathrm{m}}$}

Only $11.1 \%$ of the respondents believed that heavy metals were harmful to human health. Some few food handlers $(6.8 \%)$ knew that heavy metals damage the liver and cause stunting in children. Nonetheless, $11.9 \%$ of the food handlers thought that heavy metal-contaminated rice could not be exported to some countries. Decreased neuro development, delayed growth and early life stunting have been correlated with heavy metal consumption (Gleason, 2017, Cusick et al., 2018). Children absorb heavy metals more readily than adults which in turn cause intestinal malfunction and malabsorption of food in the infants body resulting into stunting (Horton et al., 2013). Regulation of heavy metals is done to demonstrate the capability of the exporting countries to offer food safety protection levels equivalent to those achieved in destination markets (Humphrey, 2017). The level of education was the unique predictor that influenced the attitude of food handlers towards heavy metal contamination.

Growing rice in swampy and flooded conditions and application of heavy metal- contaminated fertilizes and agrochemicals were identified as the main causes of heavy metal contamination in rice. Almost all food handlers were acquainted with cooking rice in uncontaminated water to reduce the risk of heavy metal contamination. A study conducted in China explained that washing and cooking of rice in uncontaminated water lowers the toxicological risk by reducing concentrations and bio accessibilities of $\mathrm{Cd}$, $\mathrm{As}$ and $\mathrm{Pb}$ (Liu et al., 2018).

The significant demographic factors that influenced practices of food handlers towards heavy metal contamination were education, sex, marital status and districts where respondents lived (Table 7). The level of education was the unique predictor that mainly influenced the practices of food handlers towards heavy metal contamination. 
Table 7. Practices of food handlers in the rice value chain of Uganda and the unique predictors of heavy metal contamination

\begin{tabular}{|c|c|c|c|c|c|c|c|c|}
\hline \multirow{2}{*}{ Variables } & \multirow{2}{*}{$\begin{array}{l}\text { Frequency } \\
\text { (percentage) }\end{array}$} & \multirow{2}{*}{$\begin{array}{l}\text { Significant independent } \\
\text { variables }\end{array}$} & \multirow{2}{*}{$\begin{array}{l}\text { Unique } \\
\text { predictor }\end{array}$} & \multirow{2}{*}{$\mathbf{R}^{2}$} & \multirow{2}{*}{$\begin{array}{l}\beta \\
\text { coefficient }\end{array}$} & \multirow{2}{*}{$\begin{array}{l}\text { Standard } \\
\text { error }\end{array}$} & \multicolumn{2}{|c|}{$\begin{array}{l}95 \% \text { Confidence } \\
\text { interval for } \beta\end{array}$} \\
\hline & & & & & & & $\begin{array}{l}\text { Lower } \\
\text { bound }\end{array}$ & $\begin{array}{l}\text { Upper } \\
\text { bound }\end{array}$ \\
\hline \multicolumn{9}{|l|}{ Practices that cause heavy metal contamination } \\
\hline \multirow[t]{3}{*}{ Mining } & & Education & & & & & & \\
\hline & $34(13.5)$ & Marital status & Education & 0.35 & 0.23 & 0.02 & 0.188 & 0.277 \\
\hline & & District & & & & & & \\
\hline \multirow{3}{*}{$\begin{array}{l}\text { Use of heavy metal contaminated } \\
\text { fertilizers }\end{array}$} & & Education & & & & & & \\
\hline & $66(26.2)$ & Marital status & Education & 0.49 & 0.35 & 0.03 & 0.303 & 0.404 \\
\hline & & District & & & & & & \\
\hline \multirow{3}{*}{$\begin{array}{l}\text { Use of heavy metal contaminated } \\
\text { agrochemicals }\end{array}$} & & Education & & & & & & \\
\hline & $64(25.4)$ & Marital status & Education & 0.47 & 0.34 & 0.03 & 0.288 & 0.384 \\
\hline & & District & & & & & & \\
\hline \multirow{2}{*}{$\begin{array}{l}\text { Irrigation with heavy metal contaminated } \\
\text { wastewater }\end{array}$} & & Education & & & & & & \\
\hline & $39(15.5)$ & Marital status & Education & 0.38 & 0.27 & 0.02 & 0.230 & 0.319 \\
\hline \multirow{3}{*}{$\begin{array}{l}\text { Growing rice in swampy and flooded } \\
\text { conditions }\end{array}$} & & Education & & & & & & \\
\hline & $64(25.4)$ & Marital status & Education & 0.47 & 0.34 & 0.03 & 0.288 & 0.385 \\
\hline & & District & & & & & & \\
\hline $\begin{array}{l}\text { Disposal of heavy metal contaminated } \\
\text { waste on land }\end{array}$ & $8(3.2)$ & $\begin{array}{l}\text { Education } \\
\text { District }\end{array}$ & District & 0.06 & 0.01 & 0.01 & 0.002 & 0.024 \\
\hline \multicolumn{9}{|l|}{ Ways of reducing heavy metal contamination* } \\
\hline Soaking and rinsing of rice before cooking & $13(5.2)$ & Sex & Sex & 0.09 & 0.14 & 0.03 & 0.083 & 0.191 \\
\hline Using uncontaminated water to cook rice & $249(98.8)$ & Education & Education & 0.04 & 0.03 & 0.01 & 0.010 & 0.043 \\
\hline $\begin{array}{l}\text { Cooking rice with excess water and } \\
\text { draining it when rice softens. }\end{array}$ & $8(3.2)$ & Sex & Sex & 0.05 & 0.08 & 0.02 & 0.040 & 0.128 \\
\hline
\end{tabular}

Values in parenthesis ( ) represent percentage 
3.4 Knowledge, Attitude and Practices of Food Handlers on Pesticide Contamination

Knowledge of pesticide contamination among the food handlers is presented in Table 8.

Table 8. Knowledge of food handlers in the rice value chain of Uganda and the unique predictors of pesticide contamination

\begin{tabular}{|c|c|c|c|c|c|c|c|c|c|}
\hline \multirow{2}{*}{ Variables } & \multirow{2}{*}{$\begin{array}{l}\text { Frequency (n) } \\
\text { Percentage } \\
(\%)\end{array}$} & \multirow{2}{*}{$\begin{array}{l}\text { Significant } \\
\text { variables }\end{array}$} & \multirow{2}{*}{ independent } & \multirow{2}{*}{$\begin{array}{l}\text { Unique } \\
\text { predictor }\end{array}$} & \multirow{2}{*}{$\mathbf{R}^{2}$} & \multirow{2}{*}{$\begin{array}{l}\beta \\
\text { coefficient }\end{array}$} & \multirow{2}{*}{$\begin{array}{l}\text { Standard } \\
\text { error }\end{array}$} & \multicolumn{2}{|c|}{$\begin{array}{l}95 \% \text { Confidence interval } \\
\text { for } \beta\end{array}$} \\
\hline & & & & & & & & $\begin{array}{l}\text { Lower } \\
\text { bound }\end{array}$ & $\begin{array}{l}\text { Upper } \\
\text { bound }\end{array}$ \\
\hline \multicolumn{10}{|c|}{ Have you ever been formally trained on pesticide use? } \\
\hline Yes & $80(31.7)$ & District & & & & & & & \\
\hline No & $172(68.3)$ & $\begin{array}{l}\text { Education } \\
\text { Occupation } \\
\text { Age }\end{array}$ & & District & 0.46 & -0.10 & 0.01 & -0.123 & -0.070 \\
\hline \multicolumn{10}{|c|}{ What is your source of information on pesticides? } \\
\hline $\begin{array}{l}\text { Pesticide sellers } \\
\text { Fellow food handlers } \\
\text { TV/Internet/newspapers }\end{array}$ & $\begin{array}{l}92(36.5) \\
46(18.3) \\
114(45.2)\end{array}$ & $\begin{array}{l}\text { District } \\
\text { Age }\end{array}$ & & District & 0.40 & 0.26 & 0.02 & 0.217 & 0.302 \\
\hline \multicolumn{10}{|c|}{ Might you know that some pesticides have been banned? } \\
\hline $\begin{array}{l}\text { Yes } \\
\text { No }\end{array}$ & $\begin{array}{l}141(55.9) \\
111(44.0)\end{array}$ & $\begin{array}{l}\text { Education } \\
\text { District }\end{array}$ & & District & 0.81 & 0.09 & 0.01 & 0.066 & 0.103 \\
\hline \multicolumn{10}{|c|}{ Why have some pesticides been banned? } \\
\hline Stopped production & $20(7.9)$ & & & & & & & & \\
\hline $\begin{array}{l}\text { Toxicity } \\
\text { Forbidden by nation }\end{array}$ & $\begin{array}{l}76(30.2) \\
37(14.7)\end{array}$ & $\begin{array}{l}\text { Education } \\
\text { District }\end{array}$ & & District & 0.56 & -0.23 & 0.02 & -0.270 & -0.182 \\
\hline No idea & $119(47.2)$ & & & & & & & & \\
\hline \multicolumn{10}{|c|}{ Have you ever heard of pesticide residues? } \\
\hline $\begin{array}{l}\text { Yes } \\
\text { No }\end{array}$ & $\begin{array}{l}127(50.4) \\
125(49.6)\end{array}$ & $\begin{array}{l}\text { Education } \\
\text { District }\end{array}$ & & District & 0.67 & 0.05 & 0.01 & 0.035 & 0.071 \\
\hline
\end{tabular}




\title{
Macrothink
}

Journal of Food Industry

ISSN 1948-545X

What are the commonest routes of pesticide exposure?

Inhalation $190(75.4)$

Ingestion

56 (22.2) Education

$6(2.4)$

Education

$0.36-0.37$

0.03

$-0.429$

$-0.306$

What symptoms might one have due to pesticide exposure*?

$\begin{array}{lcl}\text { Skin rash and irritation } & 217(86.1) & \begin{array}{l}\text { Occupation } \\ \text { Age }\end{array} \\ \text { Headache and dizziness } & 148(58.7) & \begin{array}{l}\text { Occupation } \\ \text { Occupation } \\ \text { District }\end{array} \\ \text { Nausea and vomiting } & 106(42.1) & \begin{array}{l}\text { Occupation } \\ \text { Excessive sweating }\end{array} \\ \text { Coughing } & 100(39.7) & \begin{array}{l}\text { Occupation } \\ \text { District }\end{array} \\ \text { Eye irritation and redness/blurred vision } & 159(63.1) & \begin{array}{l}\text { Occupation } \\ \text { Family size }\end{array} \\ \text { Respiratory distress } & & \text { Occupation } \\ \text { Fatigue } & 98(38.9) & \text { 0ccupation }\end{array}$

Age

\begin{abstract}
0.490 .07
\end{abstract}
0.01

0.040

0.090

Occupation

$0.29-0.40$

0.04

$-0.047$

$-0.316$

Occupation

$0.11-0.31$

0.05

$-0.418$

$-0.200$

Occupation

$0.06-0.18$

Occupation

$0.27-0.38$

0.05

$-0.267$

$-0.090$

Occupation

$0.19-0.28$

0.05

$-0.380$

$-0.170$

Occupation

$0.05-0.16$

0.05

$-0.251$

$-0.074$

Occupation

$0.25-0.35$

0.04

$-0.428$

$-0.275$

* Denotes more than one answer was reported (not mutually exclusive)

Values in parenthesis ( ) represent percentage 


\section{Macrothink}

Journal of Food Industry ISSN 1948-545X

Most (68.3\%) of the food handlers in this study had never received formal training in pesticide use and safety (table 8 ). The remaining $31.7 \%$ of the food handlers had received some knowledge on pesticide use from television and newspaper articles (45.2\%), and pesticide sellers $(36.5 \%)$. Some of the respondents $(30.2 \%)$ knew that some pesticides had been banned due to their toxicity. A fair number of respondents $(50.4 \%)$ had heard of pesticide residues. Inhalation $(75.4 \%)$ and ingestion $(22.2 \%)$ were the major reported routes of pesticide exposure. The majority $(86.1 \%)$ of food handlers in this study were well aware of the harmful effects of pesticides on human health, but on the contrary, this did not significantly change their practices or attitudes towards safe pesticide use.

A similar study on the knowledge and perception of farmers regarding pesticide usage in India stated that $90 \%$ of the farmers had not received any training on pesticide use, hence the limited knowledge they had (Sai et al., 2019). Pesticide vendors can be utilized as a source of sufficient and trustworthy information that can lead to a better understanding of pesticide risks and use of preventative measures, even for food handlers that are not highly educated (Sharafi et al., 2018). On the other hand,educated food handlers can read publications and access information through the internet, thus increasing their knowledge (Öztaş et al., 2018). Given that only $30.2 \%$ of the respondents knew about banned pesticides, food handlers should be informed about the names and reason for banning certain pesticides, and the effects they may induce on human health and the environment (Sharafi et al., 2018). A similar study by Gesesew et al. (2016) reported ingestion (88.9\%) and inhalation (90.4\%) as possible mechanisms of pesticide exposure. Unsafe practices and attitudes towards pesticide use were similarly reported about the rice value chain in Madagascar (Bockel et al., 2016) and Turkey (Öztaş et al., 2018). 


\section{Macrothink}

Journal of Food Industry

ISSN 1948-545X

Table 9. Attitude of food handlers in the rice value chain of Uganda and the unique predictors of pesticide contamination

\begin{tabular}{|c|c|c|c|c|c|c|c|c|}
\hline \multirow{2}{*}{ Variables } & \multirow{2}{*}{$\begin{array}{l}\text { Frequency (n) } \\
\text { Percentage }(\%)\end{array}$} & \multirow{2}{*}{ Significant independent variables } & \multirow{2}{*}{ Unique predictor } & \multirow{2}{*}{$\mathbf{R}^{2}$} & \multirow{2}{*}{$\beta$ coefficient } & \multirow{2}{*}{ Standard error } & \multicolumn{2}{|c|}{ 95\% Confidence interval for $\beta$} \\
\hline & & & & & & & Lower bound & Upper bound \\
\hline \multicolumn{9}{|c|}{ Pesticides are harmful for human health } \\
\hline Strongly agree & $31(12.3)$ & \multirow{5}{*}{$\begin{array}{l}\text { Education } \\
\text { District }\end{array}$} & \multirow{5}{*}{ District } & \multirow{5}{*}{0.683} & \multirow{5}{*}{0.064} & \multirow{5}{*}{0.017} & \multirow{5}{*}{0.032} & \multirow{5}{*}{0.097} \\
\hline Agree & $96(38.1)$ & & & & & & & \\
\hline No idea & $84(33.3)$ & & & & & & & \\
\hline Disagree & $39(15.5)$ & & & & & & & \\
\hline Strongly disagree & $2(0.8)$ & & & & & & & \\
\hline \multicolumn{9}{|c|}{ Illness is related with pesticide application } \\
\hline Strongly agree & $59(23.4)$ & & & & & & & \\
\hline Agree & $67(26.6)$ & \multicolumn{7}{|l|}{ Education } \\
\hline No idea & $69(27.4)$ & District & Education & 0.574 & 0.985 & 0.071 & 0.845 & 1.125 \\
\hline Disagree & $36(14.3)$ & \multirow{2}{*}{\multicolumn{7}{|c|}{ Family size }} \\
\hline Strongly disagree & $21(8.3)$ & & & & & & & \\
\hline \multicolumn{9}{|c|}{ Pesticides can be transferred through rice to humans } \\
\hline Strongly agree & $25(4.4)$ & \multirow{5}{*}{$\begin{array}{l}\text { Education } \\
\text { District }\end{array}$} & \multirow{5}{*}{ Education } & \multirow{5}{*}{0.179} & \multirow{5}{*}{0.668} & \multirow{5}{*}{0.096} & \multirow{5}{*}{0.478} & \multirow{5}{*}{0.858} \\
\hline Agree & $41(9.9)$ & & & & & & & \\
\hline No idea & $69(27.4)$ & & & & & & & \\
\hline Disagree & $49(31.3)$ & & & & & & & \\
\hline Strongly disagree & $68(27.0)$ & & & & & & & \\
\hline \multicolumn{9}{|c|}{ Pesticides are indispensable for high crop yield } \\
\hline Strongly agree & $62(24.6)$ & & & & & & & \\
\hline Agree & $84(33.3)$ & Education & & & & & & \\
\hline No idea & $30(11.9)$ & District & District & 0.162 & 0.207 & 0.038 & 0.131 & 0.282 \\
\hline Disagree & $57(22.6)$ & Age & & & & & & \\
\hline Strongly agree & $19(7.5)$ & & & & & & & \\
\hline
\end{tabular}

Values in parenthesis ( ) represent percentage. 


\section{Macrothink institute}

While $41.6 \%$ of the respondents in this study agreed that pesticides are harmful to human beings, $48.4 \%$ had experienced medical problems after pesticide application (table 9). However, majority (58.3\%) felt that the exposure was higher in the field than through the consumption of rice (14.3\%). Majority of the respondents (57.9\%) agreed that pesticides are indispensable for high crop yield while $21.8 \%$ felt that rice would still perform well with minimal pesticide application. To reduce the risk associated with pesticides, it is also important to educate farmers about alternative cropping systems that are less dependent on pesticides, integrated pest management practices and organic methods of pest control (Öztaş et al., 2018).

Table 10. Practices of food handlers in the rice value chain of Uganda and the unique predictors of pesticide contamination

\begin{tabular}{|c|c|c|c|c|c|c|c|c|}
\hline \multirow[t]{2}{*}{ Variables } & \multirow{2}{*}{$\begin{array}{l}\text { Frequency (n) } \\
\text { Percentage } \\
(\%)\end{array}$} & \multirow{2}{*}{$\begin{array}{l}\text { Significant } \\
\text { independent } \\
\text { variables }\end{array}$} & \multirow{2}{*}{$\begin{aligned} & \text { Unique } \\
- & \text { predictor }\end{aligned}$} & \multirow[t]{2}{*}{$\mathbf{R}^{2}$} & \multirow{2}{*}{$\begin{array}{l}\beta \\
\text { coefficient }\end{array}$} & \multirow{2}{*}{$\begin{array}{l}\text { Standard } \\
\text { error }\end{array}$} & \multicolumn{2}{|c|}{$\begin{array}{l}\text { 95\% Confidence interval for } \\
\beta\end{array}$} \\
\hline & & & & & & & Lower bound & Lower bound \\
\hline \multicolumn{9}{|l|}{ Where do you keep your pesticides? } \\
\hline A special pesticide storehouse & $229(8.7)$ & District & & & & & & \\
\hline In the living house & $101(40.1)$ & Age & District & 0.36 & 0.16 & 0.02 & 0.122 & 0.189 \\
\hline Purchase enough for use & $129(51.2)$ & Education & & & & & & \\
\hline \multicolumn{9}{|l|}{ How do you use pesticides? } \\
\hline According to instruction on the bottle & $21(8.3)$ & District & & & & & & \\
\hline Experience & $105(41.6)$ & Age & District & 036 & 0.18 & 002 & 0138 & 0217 \\
\hline By an expert advice & $126(50.0)$ & $\begin{array}{l}\text { Education } \\
\text { Occupation }\end{array}$ & & & & & & \\
\hline \multicolumn{9}{|c|}{ Which type of protection do you use when applying pesticides? } \\
\hline Face protection & $33(13.0)$ & Occupation & & & & & & \\
\hline Nose protection & $127(50.4)$ & Education & & & & & & \\
\hline Hand protection & $59(23.4)$ & District & Education & 0.61 & 0.54 & 0.05 & 0.445 & 0.625 \\
\hline Full cloth protection & $33(13.0)$ & $\begin{array}{l}\text { Marital } \\
\text { status }\end{array}$ & & & & & & \\
\hline
\end{tabular}


Where do you dispose your leftover pesticide solutions?

Re-applying on the rice until it is empty

$173(68.7)$

Storing for another application

$34(13.5)$

Occupation

Applying on other crops in the nearby garden

39 (15.5)

Age

District

$0.59-0.10$

0.02

$-0.145$

0.063

Releasing in water streams

$6(2.4)$

district

How do you dispose off empty containers?

Throwing away in the land/water streams

Disposing with regular wastes

27 (10.7)

Keeping for reuse for other purposes

$116(46.0)$

Burying them

$53(21.0)$

District

Collecting and selling them

$8(3.2)$

What is the most effective way for reducing the risk of pesticides exposure?

Dose reduction

Low-risk products

$31(12.3)$

Personal protection

$158(62.7)$

$63(25.0)$

District

Values in parenthesis ( ) represent percentage.
Education

Occupation 
The study showed that $40.1 \%$ of the food handlers stored their pesticides in the living houses (table 10). Only $8.7 \%$ of the respondents' locked pesticides in a chemical store while $51.2 \%$ bought only what they would use to spray in a given time. Half of the respondents depended on expert pesticide sellers to fumigate their rice stores, $8.3 \%$ read, understood and followed instructions on the pesticide bottles while $41.6 \%$ relied on their life experience to mix pesticides. About $50 \%$ of the food handlers covered their nose with a handkerchief/piece of cloth while $25 \%$ used gloves as they sprayed pesticides. Findings in this study showed low use $(13 \%)$ of full personal protective equipment (PPE) to reduce occupational exposure to pesticides. Of all the respondents, $45.6 \%$ washed their hands and face after spraying while $39.7 \%$ did not. Most respondents were not concerned about over-dosing; $68.7 \%$ of them responded that they apply the leftover solution to crops repeatedly while $15.5 \%$ applied the leftover pesticides to crops in nearby gardens, which aggregately means unnecessary use of pesticides. Some (2.4\%) respondents disposed of the excess pesticide solution into water streams. Empty pesticide containers were thrown on the land $(10.7 \%)$ or disposed away with regular waste $(46 \%)$. A few pesticide containers were collected and sold $(19.4 \%)$ or reused as containers at home for other purposes $(21 \%)$. Only $3.2 \%$ of the respondents buried the empty containers on the farms. Low-risk products $(62.7 \%)$, personal protection $(25.0 \%)$ and dose reduction $(12.2 \%)$ were perceived as the best practices in reducing the risk of exposure. The most common health complaints were skin irritation, fatigue, eye irritation and headache.

Storing pesticides in living areas can increase the potential for pesticide exposure especially for vulnerable groups such as children and pregnant mothers (Gesesew et al., 2016). storage of pesticides in special chemical stores or procuring what one can use at a given time reduces the risk of pesticide exposure. The label on the pesticide plays an important role in the correct use of the pesticide (Öztaş et al., 2018). The fact that $41.6 \%$ of the food handlers used pesticides based on experience indicates a general ignorance of the importance of pesticide labels in reducing exposure risk. The main reason mentioned by most food handlers who were not using full PPE was the discomfort under hot and humid conditions, as the environment in Uganda is characterized by high ambient temperatures sometimes exceeding $37{ }^{\circ} \mathrm{C}$. This indicates that food handlers were negligent to pesticide exposure much as they were aware of the risks associated with pesticides. Training on the use of full personal protective equipment and good personal hygiene after using pesticides can reduce occupational exposure (Lekei et al., 2014). Poor pesticide-handling and disposal practices were observed in this study. These can lead to pesticide residues in harvested rice posing a threat to human health. Implementation of a waste management system for safe disposal of pesticide wastes can be very effective especially during agricultural spraying seasons (Gesesew et al., 2016).

The significant demographic factors that influenced practices of food handlers towards pesticide contamination were education, age, occupation, marital status and districts where respondents lived (table 10). The district where respondents lived was the unique predictor that influenced the practices of food handlers towards pesticides. 


\section{$\underline{\Lambda \text { Macrothink }}$}

\subsection{Limitations to the Study}

The interpretation of results from this study may be limited by the fact that a cross-sectional design was used. Such studies do not allow causal relationships to be established. Furthermore, this study was based mainly on self-reported data, relying on the honesty of respondents, which is subject to bias from recall and social desirability.

\section{Conclusion}

Understanding food handler's level of KAP regarding contaminants and the unique predictors of their KAP is important for designing sound educational and policy strategies that can control contamination in the food value chain. In this study, rice producers and handlers were generally knowledgeable about aflatoxin and pesticide contamination but not heavy metals. Given that level of education was the unique predictor of food handlers' knowledge, it is important to develop and implement educational programs, which target areas where food handlers' knowledge is weak. Although processors had good attitudes with regards to contaminants, these did not sufficiently translate into good practices. Educational programs, which improve practices of the food handlers using measures that are simple and affordable, can promote food safety. Intervention strategies by regulatory agencies to strengthen enforcement of laws related to contaminants through regular surveillance at the farm and retail outlets are necessary for ensuring compliance to good agricultural, hygiene and manufacturing practices by food handlers that will reduce on contamination.

\section{Conflict of Interest}

The authors declare that they have no known competing financial interests or personal relationships that could have appeared to influence the work reported in this paper.

\section{Acknowledgments}

The Islamic Development Bank [Ref ID 600045782:2021-2022] supported this work. Special thanks to the food handlers who were involved in this study.

\section{References}

Abtahi, M., Fakhri, Y., Oliveri Conti, G., Keramati, H., Zandsalimi, Y., Bahmani, Z., Hosseini Pouya, R., Sarkhosh, M., Moradi, B., Amanidaz, N., \& Ghasemi, S. M. (2017). Heavy metals (As, $\mathrm{Cr}, \mathrm{Pb}, \mathrm{Cd}$ and $\mathrm{Ni}$ ) concentrations in rice (Oryza sativa) from Iran and associated risk assessment: a systematic review. Toxin Reviews, 36(4), 331-341. https://doi.org/10.1080/15569543.2017.1354307

Adeola, E. H. (2020). A Post-Harvest Management Practices among Rice Farmers in Imo State Nigeria. European Journal of Biology and Biotechnology, 1(4). https://doi.org/10.24018/EJBIO.2020.1.4.32

Adu, J. K., Fafanyo, D., Orman, E., Ayensu, I., Amengor, C. D. K., \& Kwofie, S. (2020). Assessing metal contaminants in milled maize products available on the Ghanaian market with Atomic Absorption Spectrometry and Instrumental Neutron Activation Analyser techniques. Food Control, 109, 106912. https://doi.org/10.1016/Journal of Food 
Al-Zoreky, N. S., \& Saleh, F. A. (2019). Limited survey on aflatoxin contamination in rice. Saudi Journal of Biological Sciences, 26(2), 225-231. https://doi.org/10.1016/j.sjbs.2017.05.010

Alemayehu, T., Aderaw, Z., Giza, M., \& Diress, G. (2021). <p>Food Safety Knowledge, Handling Practices and Associated Factors Among Food Handlers Working in Food Establishments in Debre Markos Town, Northwest Ethiopia, 2020: Institution-Based Cross-Sectional Study $</ \mathrm{p}>$. Risk Management and Healthcare Policy, 14, 1155-1163. https://doi.org/10.2147/RMHP.S295974

Ali, N. (2019). Aflatoxins in rice: Worldwide occurrence and public health perspectives. Toxicology Reports, 6(November), 1188-1197. https://doi.org/10.1016/j.toxrep.2019.11.007

Angubua, S. B., Schrunk, D., Imerman, P., Kateregga, J. N., Camana, E., Wang, C., Rumbeiha, W. K., Angubua Baluka, S., Kiiza Rumbeiha, W., \& Kiiza, W. (2017). Mycotoxin and metallic element concentrations in peanut products sold in Ugandan markets Mycotoxin and metallic element concentrations in peanut products sold in Ugandan markets PUBLIC INTEREST STATEMENT. 3, 1313925. https://doi.org/10.1080/23311932.2017.1313925

Barungi, M., \& Odokonyero, T. (2016). Understanding the Rice Value Chain in Uganda: Opportunities and Challenges to Increased Productivity. Economic Policy Research Centre.Research Report NO. 15, 15.

Bbosa, G., Godfrey, Kitya, D., Lubega, A., Ogwal-Okeng, J., W., W., \& B., D. (2013). Review of the Biological and Health Effects of Aflatoxins on Body Organs and Body Systems. Aflatoxins - Recent Advances and Future Prospects, August 2014. https://doi.org/10.5772/51201

Benkerroum, N. (2020). Aflatoxins: Producing-Molds, Structure, Health Issues and Incidence in Southeast Asian and Sub-Saharan African Countries. International Journal of Environmental Research and Public Health, 17(1215), 1-40. https://doi.org/doi:10.3390/ijerph17041215

Bockel, L., Debrune, O., \& Toudert, A. (2016). Rice Value chain in Madagascar. Food and Agricultural Organization (FAO), July.

Bukhari, S. (2020). (PDF) Bukhari Sample Size Calculator 2020. https://doi.org/http://dx.doi.org/10.13140/RG.2.2.27730.58563

Byakika, S., Mukisa, I. M., Wacoo, A. P., Kort, R., Byaruhanga, Y. B., \& Muyanja, C. (2019). Potential application of lactic acid starters in the reduction of aflatoxin contamination in fermented sorghum-millet beverages. International Journal of Food Contamination, 6(1), 1-6. https://doi.org/10.1186/s40550-019-0074-9

Chaiyarat, R., Sookjam, C., Eiam-Ampai, K., \& Damrongphol, P. (2015). Organochlorine pesticide levels in the food web in rice paddies of Bueng Boraphet wetland, Thailand. Environmental

Monitoring

and

Assessment,

187(5). 
https://doi.org/10.1007/s10661-015-4469-7

Chen, C., Zou, W., Chen, S., Zhang, K., \& Ma, L. (2020). Ecological and health risk assessment of organochlorine pesticides in an urbanized river network of Shanghai, China. Environmental Sciences Europe, 32(1). https://doi.org/10.1186/s12302-020-00322-9

Cusick, S. E., Jaramillo, E. G., Moody, E. C., Ssemata, A. S., Bitwayi, D., Lund, T. C., \& Mupere, E. (2018). Assessment of blood levels of heavy metals including lead and manganese in healthy children living in the Katanga settlement of Kampala, Uganda. $B M C$ Public Health 2018 18:1, 18(1), 1-8. https://doi.org/10.1186/S12889-018-5589-0

Echodu, R., Maxwell Malinga, G., Moriku Kaducu, J., Ovuga, E., \& Haesaert, G. (2019). Prevalence of aflatoxin, ochratoxin and deoxynivalenol in cereal grains in northern Uganda: Implication for food safety and health. Toxicology Reports, 6(June), 1012-1017. https://doi.org/10.1016/j.toxrep.2019.09.002

Elzupir, A. ., Alamer, A. ., \& Dutton, M. . (2015). The occurrence of aflatoxin in rice worldwide: A $\quad$ review. Toxin Reviews, 34(1), 37-42. https://doi.org/10.3109/15569543.2014.984229

Elzupir, A. ., Alamer, A. S., \& Dutton, M. F. (2017). Aflatoxin in Rice Crop: Prevalence and Assessment of Daily Exposure. Fungal Metabolites, 219-237. https://doi.org/10.1007/978-3-319-25001-4_5

Evangelou, E., Ntritsos, G., Chondrogiorgi, M., Kavvoura, F. K., Hernández, A. F., Ntzani, E. E., \& Tzoulaki, I. (2016). Exposure to pesticides and diabetes: A systematic review and meta-analysis. Environment $\quad$ International, $\quad 91, \quad 60-68$. https://doi.org/10.1016/j.envint.2016.02.013

Gesesew, H. A., Woldemichael, K., Massa, D., \& Mwanri, L. (2016). Farmers knowledge, attitudes, practices and health problems associated with pesticide use in rural irrigation $\begin{array}{lllll}\text { villages, } & \text { Southwest } & \text { Ethiopia. } & \text { PLoS } & \text { ONE, }\end{array}$ https://doi.org/10.1371/JOURNAL.PONE.0162527

Gomah, L., S Ngumbu, R., \& Voegborlo, R. B. (2019). Dietary Exposure to Heavy Metal Contaminated Rice and Health Risk to the Population of Monrovia. Journal of Environmental Science and Public Health, 03(03), 474-482. https://doi.org/10.26502/jesph.96120077

Guo, B., Hong, C., Tong, W., Xu, M., Huang, C., Yin, H., Lin, Y., \& Fu, Q. (2020). Health risk assessment of heavy metal pollution in a soil-rice system: a case study in the Jin-Qu Basin of China. Scientific Reports 2020 10:1, 10(1), 1-11. https://doi.org/10.1038/s41598-020-68295-6

Hodges, R., \& Stathers, T. (2012). Training manual for improving grain postharvest handling and storage. UN World Food Programme (Rome, Italy) and ..., July, 1-246. http://fa2q.eu/filesagri/Training Manual for Improving Grain Postharvest Handling and Storage_.pdf

Honma, T., Ohba, H., Kaneko, A., Nakamura, K., Makino, T., \& Katou, H. (2016). Effects of 
soil amendments on arsenic and cadmium uptake by rice plants (Oryza sativa L. cv. Koshihikari) under different water management practices. Soil Science and Plant Nutrition, 62(4), 349-356. https://doi.org/10.1080/00380768.2016.1196569

Horton, L. M., Mortensen, M. E., Iossifova, Y., Wald, M. M., \& Burgess, P. (2013). What Do We Know of Childhood Exposures to Metals (Arsenic, Cadmium, Lead, and Mercury) in Emerging Market Countries? International Journal of Pediatrics, 2013, 1-13. https://doi.org/10.1155/2013/872596

Humphrey, J. (2017). Food safety, trade, standards and the integration of smallholders into value chains: a review of the literature.

Jeyaramraja, P. R., Meenakshi, S. N., \& Woldesenbet, F. (2018). Relationship between drought and preharvest aflatoxin contamination in groundnut (Arachis hypogaea L.). 11(2), 187-199. https://doi.org/10.3920/WMJ2017.2248

Khammanee, N., Qiu, Y., Kungskulniti, N., Bignert, A., Meng, Y., Zhu, Z., \& Teffera, Z. L. (2020). Presence and health risks of obsolete and emerging pesticides in paddy rice and soil from Thailand and China. International Journal of Environmental Research and Public Health, 17(11). https://doi.org/10.3390/ijerph17113786

Kilimo Trust. (2018). Expanding Rice Markets in the East African Community.

Kim, K., Kabir, E., \& Ara, S. (2016). Science of the Total Environment Exposure to pesticides and the associated human health effects. Science of the Total Environment. https://doi.org/10.1016/j.scitotenv.2016.09.009

Kong, X., Liu, T., Yu, Z., Chen, Z., Lei, D., Wang, Z., Zhang, S., Zhang, H., \& Li, Q. (2018). Heavy metal bioaccumulation in rice from a high geological background area in Guizhou Province, China. International Journal of Environmental Research and Public Health, 15(10). https://doi.org/10.3390/ijerph15102281

Korley Kortei, N., Akomeah Agyekum, A., Akuamoa, F., Baffour, V. K., \& Wiisibie Alidu, H. (2019). Risk assessment and exposure to levels of naturally occurring aflatoxins in some packaged cereals and cereal based foods consumed in Accra, Ghana. Toxicology Reports, 6(June 2018), 34-41. https://doi.org/10.1016/j.toxrep.2018.11.012

Kumar, A., Pathak, H., Bhadauria, S., \& Sudan, J. (2021). Aflatoxin contamination in food crops: causes, detection, and management: a review. ..Food Production, Processing and Nutrition, 3(17). https://doi.org/10.1186/s43014-021-00064-y

Kumar, P., Mahato, D. K., Kamle, M., Mohanta, T. K., \& Kang, S. G. (2017). Aflatoxins: A global concern for food safety, human health and their management. Frontiers in Microbiology, 7(JAN), 1-10. https://doi.org/10.3389/fmicb.2016.02170

Lekei, E. E., Ngowi, A. V., \& London, L. (2014). Farmers' knowledge, practices and injuries associated with pesticide exposure in rural farming villages in Tanzania. BMC Public Health, 14(1). https://doi.org/10.1186/1471-2458-14-389 


\section{MInstitute ${ }^{\text {Macrothink }}$}

Liu, K., Zheng, J., \& Chen, F. (2018). Effects of washing, soaking and domestic cooking on cadmium, arsenic and lead bioaccessibilities in rice. Journal of the Science of Food and Agriculture, 98(10), 3829-3835. https://doi.org/10.1002/JSFA.8897

Lukwago, F. B., Mukisa, I. M., Atukwase, A., Kaaya, A. N., \& Tumwebaze, S. (2019). Mycotoxins contamination in foods consumed in Uganda: A 12-year review (2006-18). Scientific African, 3, e00054. https://doi.org/10.1016/j.sciaf.2019.e00054

Magoha, H., Kimanya, M., De Meulenaer, B., Roberfroid, D., Lachat, C., \& Kolsteren, P. (2016). Risk of dietary exposure to aflatoxins and fumonisins in infants less than 6 months of age in Rombo, Northern Tanzania. Maternal and Child Nutrition, 12(3), 516-527. https://doi.org/10.1111/MCN.12155

Mahato, D. K., Lee, K. E., Kamle, M., Devi, S., Dewangan, K. N., Kumar, P., \& Kang, S. G. (2019). Aflatoxins in Food and Feed: An Overview on Prevalence, Detection and Control Strategies. Frontiers in Microbiology, 0, 2266. https://doi.org/10.3389/FMICB.2019.02266

Mahuku, G., Nzioki, H. S., Mutegi, C., Kanampiu, F., Narrod, C., \& Makumbi, D. (2019). Pre-harvest management is a critical practice for minimizing aflatoxin contamination of maize. Food Control, 96, 219-226. https://doi.org/10.1016/J.FOODCONT.2018.08.032

Malnutrition, C., \& Gleason, K. M. (2017). Heavy Metals , Chronic Malnutrition and Neurodevelopment Among Children in Rural Bangladesh. https://dash.harvard.edu/handle/1/42066846

Marquez, J. E., Pourret, O., Faucon, M. P., Weber, S., Hoàng, T. B. H., \& Martinez, R. E. (2018). Effect of Cadmium, Copper and lead on the growth of rice in the coal mining region of Quang Ninh, Cam-Pha (Vietnam). Sustainability (Switzerland), 10(6). https://doi.org/10.3390/su10061758

Martinez-Miranda, M. M., Rosero-Moreano, M., \& Taborda-Ocampo, G. (2019). Occurrence, dietary exposure and risk assessment of aflatoxins in arepa, bread and rice. Food Control, 98, 359-366. https://doi.org/10.1016/J.FOODCONT.2018.11.046

Muzoora, S., Khaitsa, M. L., Bailey, H., \& Vuzi, P. (2017). Status on aflatoxin levels in groundnuts in Uganda. PAMJ. https://doi.org/10.11604/PAMJ.SUPP.2017.27.4.12453

Mwale, T. (2018). A multidisciplinary investigation into arsenic contamination in rice : rice preparation, arsenic knowledge and risk perception. October.

Ndong, M., Mise, N., Okunaga, M., \& Kayama, F. (2018). Cadmium , arsenic and lead accumulation in rice grains produced in Senegal river valley. Fundamental Toxicological Sciences, 5(2), 87-91.

Negash, D. (2018). A review of aflatoxin: occurrence, prevention, and gaps in both food and feed safety. Journal of Nutritional Health \& Food Engineering, Volume 8(Issue 2). https://doi.org/10.15406/JNHFE.2018.08.00268

Nkuba, J., Ndunguru, A., Madulu, R., Lwezaura, D., Kajiru, G., Chalamila, B., \& Ley, G. 


\section{MInstitute Macrothink $^{m}$}

(2016). Rice value chain analysis in Tanzania: identification of constraints, opportunities and upgrading strategies. African Crop Science Journal, 24(Suppliment), 73-87. https://doi.org/http://dx.doi.org/10.4314/acsj.v24i1.8S RICE

NPA. (2019). Government of Uganda: Third National Development Plan. National Planning Authority Uganda, 1(1). http://npa.ug/wp-content/uploads/NDPII-Final.pdf

Ntakyo, P. R., \& van den Berg, M. (2019). Effect of market production on rural household food consumption: evidence from Uganda. Food Security, 11(5), 1051-1070. https://doi.org/10.1007/s12571-019-00959-2

Okello, D. M., Bonabana-Wabbi, J., \& Mugonola, B. (2019). Farm level allocative efficiency of rice production in Gulu and Amuru districts, Northern Uganda. Agricultural and Food Economics, 7(1), 1-19. https://doi.org/10.1186/s40100-019-0140-x

Omar, N. A., Praveena, S. M., Aris, A. Z., \& Hashim, Z. (2015). Health risk assessment using in vitro digestion model in assessing bioavailability of heavy metal in rice: A preliminary study. Food Chemistry. https://doi.org/10.1016/j.foodchem.2015.04.087

Omara, T., Nassazi, W., Omute, T., Awath, A., Laker, F., Kalukusu, R., Musau, B., Nakabuye, B. V., Kagoya, S., Otim, G., \& Adupa, E. (2020). Aflatoxins in Uganda: An Encyclopedic Review of the Etiology, Epidemiology, Detection, Quantification, Exposure Assessment, Reduction, and Control. International Journal of Microbiology, 2020. https://doi.org/10.1155/2020/4723612

Oniya, E. O., Olubi, O. E., Ibitoye, A., Agbi, J. I., Agbeni, S. K., \& Faweya, E. B. (2018). Effect of Milling Equipment on the Level of Heavy Metal Content of Foodstuff. Physical Science International Journal, 20(2), 1-8. https://doi.org/10.9734/PSIJ/2018/42572

Öztaş, D., Kurt, B., Koç, A., Akbaba, M., \& Ilter, H. (2018). Knowledge level, attitude, and behaviors of farmers in çukurova region regarding the use of pesticides. BioMed Research International, 2018. https://doi.org/10.1155/2018/6146509

Palliyaguru, D. L., \& Wu, F. (2013). Global geographical overlap of aflatoxin and hepatitis C: Controlling risk factors for liver cancer worldwide. Food Additives and Contaminants - Part A Chemistry, Analysis, Control, Exposure and Risk Assessment, 30(3), 534-540. https://doi.org/10.1080/19440049.2012.751630

Ray Lantin. (2019). Rice:Post-harvest Operations. https://www.fao.org/publications/card/en/c/804bd57b-8f3c-4c6b-b73d-9c18848ffc7f/

Sai, M. V. S., Revati, G. D., Ramya, R., Swaroop, A. M., Maheswari, E., \& Kumar, M. M. (2019). Knowledge and Perception of Farmers Regarding Pesticide Usage in a Rural Farming Village, Southern India. Indian Journal of Occupational and Environmental Medicine, 23(1), 32-36. https://doi.org/10.4103/IJOEM.IJOEM_121_18

Sarma, U. P., Bhetaria, P. J., Devi, P., \& Varma, A. (2017). Aflatoxins : Implications on Health. Indian Journal of Clinical Biochemistry. https://doi.org/10.1007/s12291-017-0649-2 


\section{Macrothink}

Sharafi, K., Pirsaheb, M., Maleki, S., Arfaeinia, H., Karimyan, K., Moradi, M., \& Safari, Y. (2018). Knowledge, attitude and practices of farmers about pesticide use, risks, and wastes; a cross-sectional study (Kermanshah, Iran). Science of the Total Environment, 645, 509-517. https://doi.org/10.1016/j.scitotenv.2018.07.132

Simon, F., Mtei, M. K., \& Kimanya, M. (2016). Heavy Metals Contamination in Agricultural Soil and Rice in Tanzania: A Review. International Journal of Environmental Protection and Policy, 4(1), 16. https://doi.org/10.11648/j.ijepp.20160401.13

Smith, L. E., Stoltzfus, R. J., \& Prendergast, A. (2012). Food chain mycotoxin exposure, gut health, and impaired growth: A conceptual framework. Advances in Nutrition, 3(4), 526-531. https://doi.org/10.3945/an.112.002188

Swagata, S., Juliana, D. bernades gil, Keeley, J., Mohring, N., \& Jansen, K. (2021). The use of pesticides in developing countries and their impact on health and the right to food (D. Gregory (ed.); Issue January). European Parliament. https://doi.org/10.2861/953921

Udomkun, P., Wossen, T., Nabahungu, N. L., Mutegi, C., Vanlauwe, B., \& Bandyopadhyay, R. (2018). Incidence and farmers' knowledge of aflatoxin contamination and control in Eastern Democratic Republic of Congo. Food Science and Nutrition, 6(6), 1607-1620. https://doi.org/10.1002/fsn3.735

Wu, W., Wu, P., Yang, F., Sun, D., Zhang, D., \& Zhou, Y. (2018). Science of the Total Environment Assessment of heavy metal pollution and human health risks in urban soils around an electronics manufacturing facility. Science of the Total Environment, 630, 53-61. https://doi.org/10.1016/j.scitotenv.2018.02.183

Zulkafflee, N. S., Redzuan, N. A. M., Hanafi, Z., Selamat, J., Ismail, M. R., Praveena, S. M., \& Razis, A. F. A. (2019). Heavy metal in paddy soil and its bioavailability in rice using in vitro digestion model for health risk assessment. International Journal of Environmental Research and Public Health, 16(23). https://doi.org/10.3390/ijerph16234769

\section{Copyright Disclaimer}

Copyright for this article is retained by the author(s), with first publication rights granted to the journal.

This is an open-access article distributed under the terms and conditions of the Creative Commons Attribution license (http://creativecommons.org/licenses/by/4.0/). 